\title{
When supply meets demand: wage inequality in Portugal
}

\author{
Mário Centeno and Álvaro A Novo*
}

\author{
*Correspondence: \\ alvaro.a.novo@gmail.com \\ Research Department, Banco de \\ Portugal, Av. Almirante Reis, 71 \\ 1150 Lisboa, Portugal
}

\begin{abstract}
Wage inequality in Portugal has increased over the last thirty years, with two distinct periods. The period from 1984 to the mid-90s witnessed strong increases in both upper- and lower-tail inequality. A shortage of skills combined with skill-biased technological changes were at the core of this evolution. Since the mid-90s, lower-tail inequality has decreased, while upper-tail inequality has increased, but at a slower rate. A larger supply of skills and polarization of labor demand contribute to this evolution. Other developed economies share similar trends, but the Portuguese experience shows clearly the role of supply and demand factors in shaping the wage distribution.
\end{abstract}

JEL codes: J3; D3; O3

Keywords: Inequality; Polarization; Supply; Demand

\section{Introduction}

The debate over the level and trends in wage inequality in developed economies has evolved around a continental divide. In the 80 s and 90s, inequality was high and increasing in Anglo-Saxon countries (Autor et al. 2008; Card and Lemieux 2001), while it remained stable in Continental Europe. Recently, this view has been challenged, with a reassessment of inequality developments in some European countries, in particular in Germany (Dustmann et al. 2009). The more recent evidence points to a significant increase in inequality in Europe (OECD 2011). We contribute to this debate and stress the key role of supply and demand factors to explain wage inequality in Portugal.

Using a supply, demand, and institutions framework, we study the determinants of inequality in the period from 1984 to 2009. Portugal is frequently depicted as a highly regulated labor market in which institutions promote rigid wage and employment adjustments. We challenge this view and show that demand factors - skill-biased technological change and polarization - and supply factors - the large increase in skill supply - have shaped the changes in inequality. We uncover a low elasticity of substitution between high- and low-skill workers that also helps in explaining the large skill wage premium.

Demand and supply conditions have changed quite substantially in Portugal, making it an interesting case to trace the sources for wage inequality in labor market forces. In addition, the institutional framework of the Portuguese labor market - collective bargaining, minimum wage, and employment protection - were already in place before 1984 . Using data from Quadros de Pessoal - a comprehensive employer-employee matched dataset

(o)2014 Centeno and Novo; licensee Springer. This is an Open Access article distributed under the terms of the Creative

Commons Attribution License (http://creativecommons.org/licenses/by/4.0), which permits unrestricted use, distribution, and reproduction in any medium, provided the original work is properly credited. 
of private sector employment - we find a continuous increase in overall inequality from 1984 to 2009 . Throughout the 80 s and until the mid-90s, wage inequality increased steeply at both ends of the wage distribution. The supply of skills remained quite low during the first period, but a large shift occurred during the 90s, with the share of college graduates almost tripling, from $5 \%$ to $14 \%$. Wage inequality fell at the lower-tail and slowed down at the upper-tail.

A counterfactual analysis suggests that the main contribution to the increase in inequality in the initial period was the result of demand factors, generating positive price effects, while mild composition effects also pushed inequality up. In the second period, there are negative price effects (contributing to a reduction in inequality), offset by positive composition effects (that pushed inequality up).

A simple demand and supply model explains about $80 \%$ of the wage premium variation (Katz and Murphy 1992). The educational supply shifts were reinforced by an increase in female participation and immigration, which are groups with educational attainment above the average. In addition, the demand for skills was fueled by European Community accession (1986), euro membership (1998) and large FDI flows.

The extraordinary increase in the supply of skills generated divergent paths for the college wage gap by experience group. This shift has compressed the college wage premium for less experienced individuals since the early 90s. For more experienced workers (20 or more years of work), the college wage premium increased steadily, and has only flattened out recently. The different trends in college supply by experience group explain $82 \%$ of the increase in the gap of the college wage premium between younger and older workers. Wage inequality in Portugal seems to be the result of a race between education and technology. In the first part of the sample, technology wins over education, while more recently education picks up with the pace of the demand for skills.

The Portuguese experience resembles the evolution of inequality in the U.S. Both have a low elasticity of substitution between high and low skills, implying a strong reaction of the wage skill premium to relative supply conditions. They also share negative price effects in the more recent period associated with the reduction in lower-tail inequality (minimum wage developments).

Previous studies of wage inequality in Portugal include Cardoso (1998), Machado and Mata (2001), Martins and Pereira (2004), Cardoso (2004) and Machado and Mata (2005). These studies cover only the first half of our sample. Machado and Mata (2005) extend the analysis with counterfactual price and composition effects, using a quantile regression decomposition method. For the overlapping period, the wage premium estimates reported in these studies are in line with the ones we obtain.

The ability of simple supply and demand models to explain wage inequality in Portugal and the similarities with the results obtained for the U.S. provide relevant lessons for the design of policies - such as the minimum wage and education - to tackle the growing wage inequality in Europe. The scope for general redistributive policies should be evaluated in conjunction with the role played by two important market factors: the supply of education and the demand for skills.

\section{Data}

Quadros de Pessoal (QP) is an administrative dataset collected on an annual basis (reported to March of each year until 1993 and to October since then) by the Portuguese 
Ministry of Employment. Coverage is mandatory for firms with at least one salaried worker, except for civil servants, entities that employ non-permanent rural workers, and domestic workers. This dataset has been used to study different aspects of the Portuguese labor market, among which wage inequality in Machado and Mata (2001) and Cardoso (2004).

We use data from 1984 to 2009 , with the exception of the years for which the data were not collected, 1990 and 2001. ${ }^{1}$ For the purpose of this study, we collect the monthly wage, hours worked, age, education, and occupation of workers. In 2009, the data covered nearly 3 million employees.

QP registers different wage components and hours worked. We use the base wage measure, which corresponds to the monthly wage of regular working hours. Additionally, we consider a total wage measure that includes, besides the base wage, subsidies paid on a monthly basis (e.g. seniority), bonuses, and overtime pay. Details about the sample construction are deferred to the Appendix.

\section{The Portuguese wage structure}

Figure 1 and Table 1 display basic features of the Portuguese economy wage structure for male and female workers from 1984 to 2009. Figure 1 illustrates the non-monotonic widening of the wage distribution over this long period for both male and female workers. The 90th percentile increases by approximately $35 \log$ points $(\times 100)$ relative to the median for both males and females. The main difference between male and female inequality changes in the period occur below the median, with higher wage growth for females.

The Portuguese labor market was characterized by significant demographic and educational changes in this period. Table 2 takes a closer look at the evolution of inequality within groups of age and education. We use the 50th to 10th and 90th to 50th percentiles log wage gaps and employment shares to illustrate price and quantity trends.

There is an impressive shift in the supply of skills. The share of low-skill individuals (those with 6 or less years of schooling) decreased by 28 percentage points, while the share of high-skill workers rose from $3 \%$ in 1984 to $14 \%$ in 2009 . The age composition of the

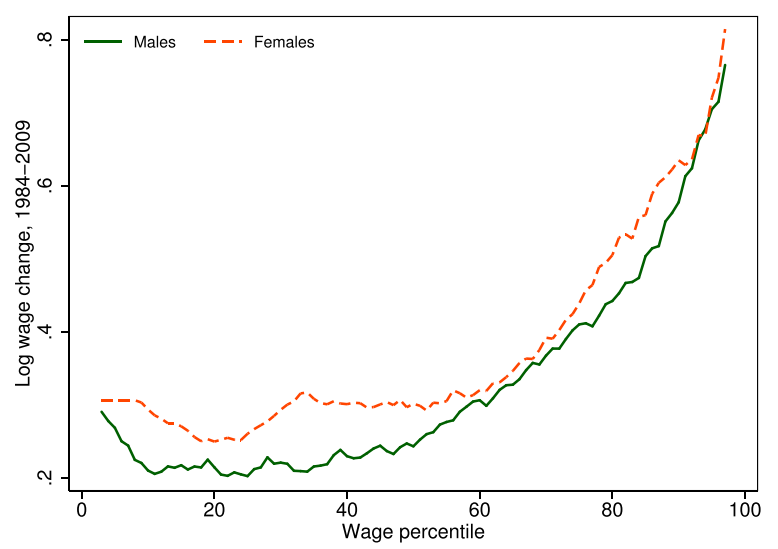

Figure 1 Log wage distribution percentile changes, 1984-2009 (M/F). Source: Quadros de Pessoal data for 1984 and 2009, full-time workers aged 16 to 65 with 0 to 39 years of potential experience. Full-time workers are those who worked $35+$ hours per week and earned at least the minimum wage. Calculations were deflated using the consumer price index. 
Table 1 Summary statistics

\begin{tabular}{lccc}
\hline & $\mathbf{1 9 8 4}$ & $\mathbf{1 9 9 5}$ & $\mathbf{2 0 0 9}$ \\
\hline & Minimum wage & & \\
Log real minimum wage (1982 prices) & 3.875 & 3.992 & 4.18 \\
Percentage of minimum wage earners & 4.246 & 8.533 & 14.429
\end{tabular}

\begin{abstract}
All workers
1-9 years of experience

10-19 years of experience

20-29 years of experience

$30+$ years of experience
\end{abstract}

College wage premium (Log points)

$\begin{array}{lll}0.675 & 0.896 & 0.833 \\ 0.619 & 0.802 & 0.656 \\ 0.779 & 1.061 & 0.933 \\ 0.844 & 1.137 & 1.204 \\ 0.900 & 1.123 & 1.294 \\ & & \\ \text { Male } & & \end{array}$

Location measures

10th Percentile

$\begin{array}{lll}3.973 & 4.066 & 4.184 \\ 4.306 & 4.487 & 4.549 \\ 4.872 & 5.236 & 5.450 \\ 4.379 & 4.596 & 4.719\end{array}$

90th Percentile

4.379

4.596

4.719

Standard deviation of log wages

Standard errors of log wage residuals

Dispersion measures

$\begin{array}{lll}0.368 & 0.491 & 0.528 \\ 0.278 & 0.366 & 0.402\end{array}$

Female

10th Percentile
Median
90th Percentile
Average

Standard deviation of log wages

Standard errors of log wage residuals
Location measures

$\begin{array}{lll}3.888 & 3.992 & 4.181 \\ 4.093 & 4.230 & 4.395 \\ 4.630 & 5.001 & 5.265 \\ 4.189 & 4.378 & 4.575\end{array}$

Dispersion measures

\begin{tabular}{lll}
0.309 & 0.428 & 0.463 \\
0.231 & 0.317 & 0.330 \\
\hline
\end{tabular}

Notes: See note to Figure 1. The log wage residuals are obtained with log wage regressions that control for five education categories, eight age categories, and all possible interactions between these two variables. College wage premium computed as described in the Appendix.

working population also changed during this period. The share of young workers (under 35 ) decreased from $50 \%$ in 1984 to $42 \%$ in 2009 , and among young workers, the share of high-skill increased from $3 \%$ to close to $18 \%$.

Similarly, in Germany and the U.S., wage dispersion fans out with age and education (Dustmann et al. 2009). Table 2 highlights the fact that upper-tail wage dispersion rose within education and age groups, suggesting that workforce composition cannot fully account for the rise in inequality. However, the increase in within-group inequality was not generalized to all groups, suggesting a differentiated price effect. Within-group, lower-tail inequality increases in the first period and decreases in the second period, pointing to a price effect of opposite sign in each of the periods. 
Table 2 Within-group wage dispersion and worker share, by age and education

\begin{tabular}{|c|c|c|c|c|c|c|c|}
\hline & & \multicolumn{3}{|c|}{$\begin{array}{c}\text { Within-group } \\
\text { wage dispersion }\end{array}$} & \multicolumn{3}{|c|}{ Worker share } \\
\hline & & 1984 & 1995 & 2009 & 1984 & 1995 & 2009 \\
\hline & & \multicolumn{6}{|c|}{ Low skill } \\
\hline \multirow[t]{2}{*}{ Age $<36$} & $50 / 10$ & 0.209 & 0.217 & 0.111 & 0.287 & 0.158 & 0.085 \\
\hline & $90 / 50$ & 0.395 & 0.422 & 0.490 & & & \\
\hline \multirow[t]{2}{*}{ Age $36-45$} & $50 / 10$ & 0.355 & 0.341 & 0.199 & 0.165 & 0.132 & 0.119 \\
\hline & $90 / 50$ & 0.458 & 0.616 & 0.594 & & & \\
\hline \multirow[t]{2}{*}{ Age $>45$} & $50 / 10$ & 0.353 & 0.434 & 0.260 & 0.197 & 0.153 & 0.168 \\
\hline & $90 / 50$ & 0.496 & 0.666 & 0.763 & & & \\
\hline \multirow[t]{3}{*}{ All } & $50 / 10$ & 0.310 & 0.358 & 0.200 & 0.649 & 0.442 & 0.372 \\
\hline & $90 / 50$ & 0.455 & 0.639 & 0.667 & & & \\
\hline & & \multicolumn{6}{|c|}{ Medium skill } \\
\hline \multirow[t]{2}{*}{ Age $<36$} & $50 / 10$ & 0.420 & 0.391 & 0.239 & 0.202 & 0.340 & 0.257 \\
\hline & $90 / 50$ & 0.591 & 0.771 & 0.704 & & & \\
\hline \multirow[t]{2}{*}{ Age $36-45$} & $50 / 10$ & 0.600 & 0.785 & 0.525 & 0.072 & 0.101 & 0.135 \\
\hline & $90 / 50$ & 0.518 & 0.780 & 1.161 & & & \\
\hline \multirow[t]{2}{*}{ Age $>45$} & $50 / 10$ & 0.644 & 1.003 & 0.741 & 0.048 & 0.065 & 0.095 \\
\hline & $90 / 50$ & 0.736 & 0.784 & 1.356 & & & \\
\hline \multirow[t]{3}{*}{ All } & $50 / 10$ & 0.561 & 0.528 & 0.377 & 0.321 & 0.506 & 0.486 \\
\hline & $90 / 50$ & 0.741 & 1.100 & 1.149 & & & \\
\hline & & \multicolumn{6}{|c|}{ High skill } \\
\hline \multirow[t]{2}{*}{ Age $<36$} & $50 / 10$ & 0.731 & 0.983 & 0.786 & 0.014 & 0.028 & 0.085 \\
\hline & $90 / 50$ & 0.571 & 0.920 & 0.867 & & & \\
\hline \multirow[t]{2}{*}{ Age $36-45$} & $50 / 10$ & 0.815 & 1.220 & 1.115 & 0.009 & 0.014 & 0.038 \\
\hline & $90 / 50$ & 0.562 & 0.877 & 1.117 & & & \\
\hline \multirow[t]{2}{*}{ Age $>45$} & $50 / 10$ & 1.287 & 1.308 & 1.865 & 0.007 & 0.010 & 0.019 \\
\hline & $90 / 50$ & 0.608 & 1.000 & 1.228 & & & \\
\hline \multirow[t]{2}{*}{ All } & $50 / 10$ & 0.865 & 1.194 & 0.984 & 0.030 & 0.051 & 0.142 \\
\hline & $90 / 50$ & 0.725 & 1.082 & 1.344 & & & \\
\hline
\end{tabular}

Notes: The tabulated statistics are for both genders. See note to Figure 1. Low skill - 6 or less years of schooling; Medium skill - 7 to 12 years of schooling; High skill - college degree.

The demography changed faster between 1995 and 2009 than in the earlier period (Table 2). This led to the decomposition of the real wage percentile changes in these two periods (Figure 2). The trends in inequality are quite different for the two genders in the two periods. The first period witnessed a strong increase in male upper-tail inequality and a more modest one in the lower-tail. For females, lower-tail inequality remained constant, whereas there was a larger increase in upper-tail. In the second period, the increase in lower-tail inequality for females is negligible, while for males there is a reduction in inequality. In the upper-tail, the increase in inequality is similar for both genders but more modest in comparison with the previous period.

Given the significant change in composition, particularly on the educational side, part of the inequality evolution might be explained by these fundamentals. To account for it, we compute residual inequality measures. Table 1 presents the standard deviation of 

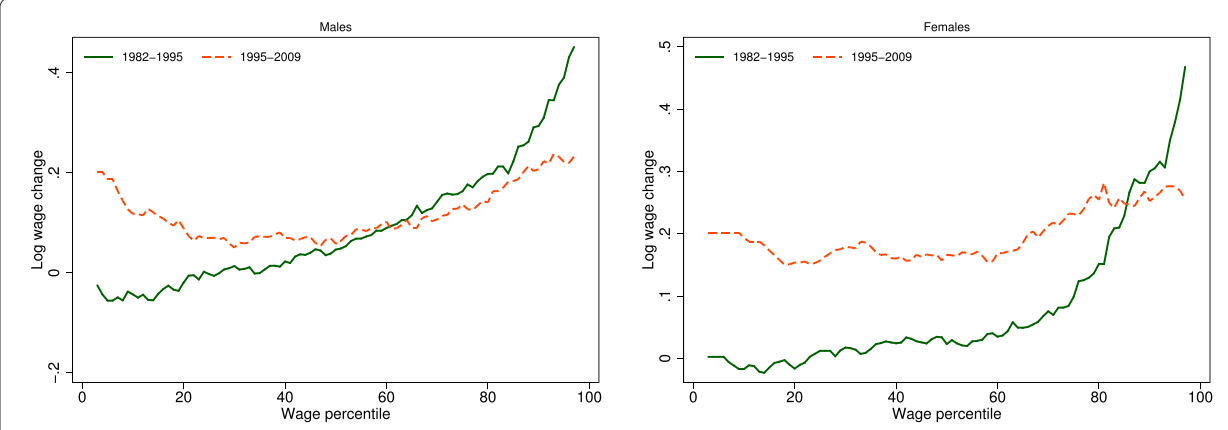

Figure 2 Log wage distribution percentile changes, Males (left panel), Females (right panel); 1984-1995 and 1995-2009. See also notes to Figure 1.

log-wages and the standard errors of the residuals obtained from OLS log-wage regressions estimated separately for each year, controlling for five education levels, eight age categories, and all possible interactions between these two variables (see the Appendix for more details). The trends in residual inequality mimic the ones obtained with overall inequality; an increase in the first period (1984-1995), from 0.278 to $0.366,8.8 \log$ points, followed by a smaller increase of $3.6 \log$ points in the $1995-2009$ period. The overall inequality increased by 12.3 and 3.7 log points in each period. The similar evolution of overall and residual inequality confirms the evidence in Table 2, where a significant fraction of the increase in wage inequality occurred within age and education groups.

The results reported used the base wage. However, institutions and market forces may have distinct effects on the different components of the total wage. We checked if the trends in wage inequality were robust to different wage definitions by using measures of total wages (base wages + other regular monthly payments + overtime pay), hourly base wages, and hourly total wages. The conclusions did not change with the inclusion of other wage components or the explicit consideration of hours. For the remainder of the paper, we stick with base wages, which are more prone to be influenced by institutional arrangements. Therefore, the estimated measures can be interpreted as upper bounds on the role of non-market forces on the evolution of inequality.

This is preliminary evidence of the role of the supply and demand shifts in shaping the evolution of Portuguese wage distribution during these 30 years. It will be explored in a more structured way in the next sections.

\subsection{The role of composition and prices}

How can we decompose the changes in inequality between the impact of the workforce composition and the prices? We observed an increase in inequality within narrowly defined age and education groups, which hints at significant price effects, but with a sign and magnitude that may have changed over time. In a partial equilibrium framework, we explore the role of composition and price effects by constructing a counterfactual wage distribution using the kernel re-weighting method developed by DiNardo et al. (1996). A caveat common in this literature is the partial equilibrium nature of the decomposition proposed, as it assumes that prices and quantities (characteristics) are independent. In the current setting, with large changes in the composition of qualifications and experience (age), this assumption of independence is likely to be violated. 


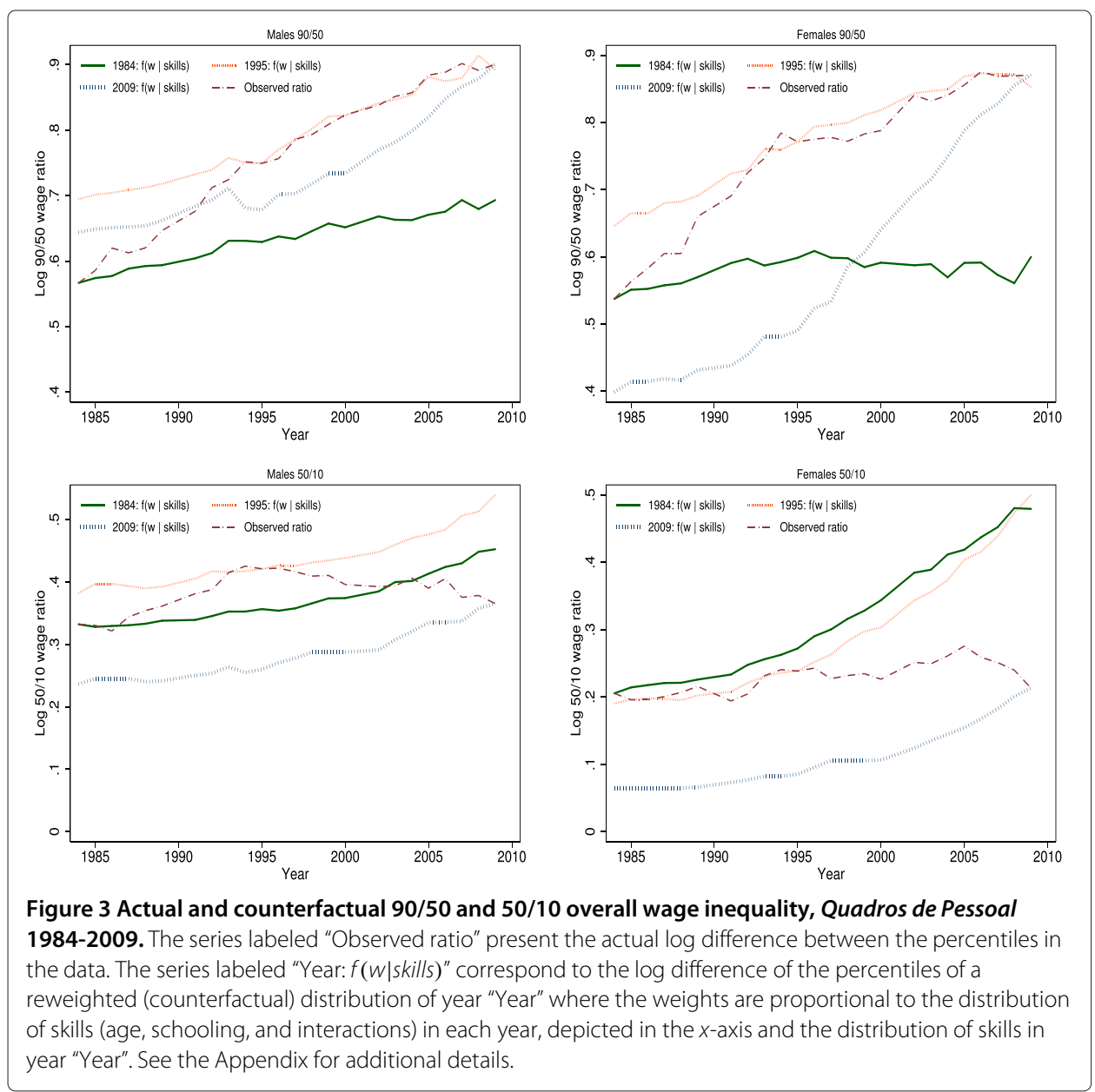

Figure 3 plots observed and counterfactual overall inequality. The three counterfactual curves plotted hold prices constant at their 1984, 1995, or 2009 levels, while labor force composition is allowed to evolve as observed over the full sample, 1984 to 2009. Thus, in these figures, a vertical difference between the curves identifies the price effect at each year, i.e., the composition is held constant at that year's level while the prices change across counterfactual curves. Movements along each counterfactual curve identify composition effects. Table 3 complements this information with the rates of change for particular years. For each wage gap, the first row shows the observed change. The following rows show the counterfactual change that would have prevailed if the workforce composition had been the same in 1984, 1995 or 2009, i.e., the price effects.

There are two distinct periods of inequality growth. Inequality grew at a faster pace from 1984 to 1995 than in the subsequent period, 1995-2009. In the upper-tail (90/50), overall male wage inequality grew by $18.3 \log$ points in the first sub-period, and after 1995 it grew by $15.2 \log$ points. If the workforce composition had remained constant at 1984 levels, the 90/50 wage gap would have increased by $12.8 \log$ points between 1984 and 1995 and decreased by $5.1 \log$ points between 1995 and 2009. The change of prices from 1984 to 1995 explains a substantial part of the observed increase in inequality, but the same is not true afterwards; the price changes from 1995 to 2009 yielded reductions or tiny increases in inequality. A tentative explanation for this change of pattern between periods 
Table 3 Observed and composition-constant changes in overall and residual inequality, log points $\times 100$

\begin{tabular}{|c|c|c|c|c|c|c|c|}
\hline & \multicolumn{3}{|c|}{ Overall inequality } & & \multicolumn{3}{|c|}{ Residual inequality } \\
\hline & 1984-1995 & 1995-2009 & 1984-2009 & & 1984-1995 & 1995-2009 & 1984-2009 \\
\hline & & & & $\Delta 90 / 50$ & & & \\
\hline & & & & Males & & & \\
\hline Observed & 18.3 & 15.2 & 33.4 & & 8.9 & 10.1 & 19.0 \\
\hline 1984 composition & 12.8 & -5.1 & 7.7 & & 8.8 & 2.6 & 11.4 \\
\hline 1995 composition & 12.0 & -7.1 & 4.9 & & 8.0 & 2.8 & 10.8 \\
\hline \multirow[t]{2}{*}{2009 composition } & 19.9 & 0.8 & 20.8 & & 10.2 & 4.5 & 14.7 \\
\hline & & & & Females & & & \\
\hline Observed & 23.4 & 9.9 & 33.3 & & 8.4 & 4.2 & 12.6 \\
\hline 1984 composition & 10.9 & -24.7 & -13.9 & & 5.3 & -10.1 & -4.8 \\
\hline 1995 composition & 17.3 & -28.1 & -10.8 & & 6.6 & -11.3 & -4.7 \\
\hline \multirow[t]{3}{*}{2009 composition } & 25.3 & 1.8 & 27.1 & & 12.2 & -5.6 & 6.6 \\
\hline & & & & $\Delta 50 / 10$ & & & \\
\hline & & & & Males & & & \\
\hline Observed & 8.9 & -5.6 & 3.3 & & 6.9 & -1.9 & 5.0 \\
\hline 1984 composition & 5.0 & -14.6 & -9.6 & & 5.7 & -12.1 & -6.3 \\
\hline 1995 composition & 6.4 & -16.1 & -9.7 & & 5.5 & -10.7 & -5.1 \\
\hline \multirow[t]{2}{*}{2009 composition } & 8.7 & -17.4 & -8.7 & & 8.0 & -10.7 & -2.7 \\
\hline & & & & Females & & & \\
\hline Observed & 3.3 & -2.5 & 0.8 & & 5.5 & 2.7 & 8.2 \\
\hline 1984 composition & -1.5 & -12.6 & -14.1 & & 1.3 & -10.5 & -9.2 \\
\hline 1995 composition & -3.4 & -15.3 & -18.7 & & 3.5 & -11.0 & -7.5 \\
\hline 2009 composition & 2.1 & -28.7 & -26.6 & & 9.6 & -14.5 & -5.0 \\
\hline
\end{tabular}

Notes: Tabulated statistics present observed and composition-constant overall and residual inequality from Quadros de Pessoal, 1984-2009. Residual inequality is obtained from a regression of log hourly wages on a full set of experience dummies, dummies for 5 discrete schooling categories, and a full set of interactions among the schooling dummies and a quartic in experience. All models are estimated separately by gender. See the Appendix for further details in the compositional adjustment method. In relation to Figure 3, the values reported in this table are obtained by subtracting pairs of counterfactual curves vertically. For instance, for overall male upper-tail inequality, the price effect induced by wage changes from 1995 to 2009 with 1984 composition, -5.1 log points, is obtained by subtracting the values in 1984 of the 2009 counterfactual curve from the 1995 counterfactual curve.

rests on the substantive shift in the supply of skills that occurred in the second period. One might speculate that demand factors explain the positive and substantial price effect of the early period, while supply increases counterbalanced the increase in demand to yield rather paltry (or negative) price effects in the more recent period. All these effects are evident in the upper left panel of Figure 3. The counterfactual curves for 1995 and 2009 are closer, resulting in smaller price effects (vertical distances). The counterfactual series (moving along the $x$ axis) are steeper after the mid-90s, implying that the contribution of compositional changes to inequality grew over time.

In the lower-tail (50/10), the first period is characterized by an increase in overall inequality of $8.9 \log$ points for males, while between 1995 and 2009 this increase is almost wiped out by a reduction of 5.6 log points. The change in prices from 1984 to 1995 explains again a substantial part of the increase in inequality. In the second period, the price change would seem to have resulted in even larger reductions in lower-tail male inequality. The composition effect cancels out part of the price effect. Although not as 
pronounced as in the upper-tail, composition effects play a larger role in the later period, which is consistent with the evidence gathered for the educational and age changes that characterized the Portuguese economy.

In Machado and Mata (2005), the returns to education and workforce composition have a similar contribution to the increase in wage inequality over the 1986-1995 period. In our case, we split the analysis by gender and obtain a larger price effect for men in upperand lower-tail inequality, but a larger composition effect for women over the same period. Thus, the results seem to be consistent in both methodologies.

The broad messages drawn for overall inequality carry over to residual inequality. Residual inequality slowed down in the final period, 1995-2009, at both ends of the distribution (see Table 3). For upper-tail inequality, price effects are more important in the earlier period, where they account for at least $60 \%$ of the rise in inequality. In the final period, composition effects play a larger role. For lower-tail inequality, a countervailing composition effect ends up canceling most of the reduction in residual inequality implied by the price effect.

\section{The sources of wage inequality}

An important component of the rise in inequality in the US is the sustained increase in the return to education (Goldin and Katz 2008). In Portugal the pattern is somewhat different due to a bigger supply shift in college educated workers and a weaker demand pressure on high-skill wages.

\subsection{The relative skill supply}

We follow Katz and Murphy's (1992) formal supply-demand framework to understand the evolution of the returns to education during the last three decades. The Katz and Murphy framework uses a two-level CES production function to explain the educational wage differentials, $\frac{w_{c t}}{w_{n t}}$, between college $(c)$ and noncollege $(n)$, with fluctuations in relative labor supply, $\frac{N_{c t}}{N_{n t}}$, and smooth trends in relative demand growth, proxied by a time trend, $t$, (see the Appendix for a more detailed description):

$$
\ln \left(\frac{w_{c t}}{w_{n t}}\right)=\alpha_{0}+\alpha_{1} t+\alpha_{2} \ln \left(\frac{N_{c t}}{N_{n t}}\right)+\alpha_{3} U R_{t}+\alpha_{4} W_{t}^{\min } .
$$

We measure the functioning of the labor market with the natural unemployment rate, $U R_{t}$. Including it in the regression accounts for structural factors, orthogonal (noncorrelated) to supply and demand, that contribute towards inequality. The inclusion of the unemployment rate would also account for more cyclical factors, which to some extent are already reflected in the demand and supply variables. The model also includes the log real minimum wage, $W_{t}^{\text {min }}$. It is important to note that since the late $90 \mathrm{~s}$, labor market conditions have deteriorated with an increase in the natural rate of unemployment (Centeno et al. 2009). Also, the real minimum wage increased by 21\% between 1995 and 2009 and $12 \%$ from 1984 to 1995 (Table 1).

Table 4 presents the estimates of the college-noncollege wage gap model. Figure 4 uses the results in column (1) in Table 4 to predict the change in the college wage premium and compares it with the actual college wage differential. This simple model does a good job in predicting the growth of the wage differential since the mid 90s. 
Table 4 Regression models for the college/noncollege log wage gap

\begin{tabular}{|c|c|c|c|c|c|}
\hline & $(1)$ & (2) & (3) & (4) & (5) \\
\hline \multirow[t]{2}{*}{ College/noncollege relative supply } & -0.678 & -0.683 & -0.713 & -0.481 & -0.378 \\
\hline & 0.129 & 0.144 & 0.127 & 0.091 & 0.098 \\
\hline \multirow[t]{2}{*}{ Log real minimum wage } & & & -0.610 & & -0.211 \\
\hline & & & 0.400 & & 0.246 \\
\hline \multirow[t]{2}{*}{ Natural unemployment rate } & & & & -0.038 & -0.043 \\
\hline & & & & 0.006 & 0.007 \\
\hline \multirow[t]{2}{*}{ Time } & 0.052 & 0.052 & 0.059 & 0.043 & 0.045 \\
\hline & 0.008 & 0.009 & 0.010 & 0.006 & 0.006 \\
\hline \multirow[t]{2}{*}{ Time*1995 } & & 0.001 & & & -0.004 \\
\hline & & 0.003 & & & 0.001 \\
\hline \multirow[t]{2}{*}{ Constant } & -1.109 & -1.116 & 1.044 & -0.409 & 0.632 \\
\hline & 0.349 & 0.381 & 1.450 & 0.258 & 0.869 \\
\hline No. of observations & 24 & 24 & 24 & 24 & 24 \\
\hline$R^{2}$ & 0.777 & 0.777 & 0.800 & 0.911 & 0.937 \\
\hline
\end{tabular}

The implied elasticity of substitution (given by $\frac{1}{\alpha_{2}}$ ) in the more complete specification in column (5) of Table 4 is around 2.6, higher than the 1.6 estimate for the U.S. in Autor et al. (2008), but only half the estimate of 5 for Germany in Dustmann et al. (2009). This is evidence of a substantive unresponsiveness of wages to shocks on the relative supply of skills in Portugal. The large pool of very low educated workers might explain the low substitutability of college and noncollege workers when compared with the estimate for Germany.

The time trend captures a demand shift that contributed to an increase in inequality. Table 4 considers the possibility of a slowdown in demand shifts since 1995. In columns (2) and (5), we interact the time trend with a post-1995 dummy, which proves to be negative and significant in the more complete specification, pointing towards some reduction of the demand pressure in the college wage gap in the recent period.

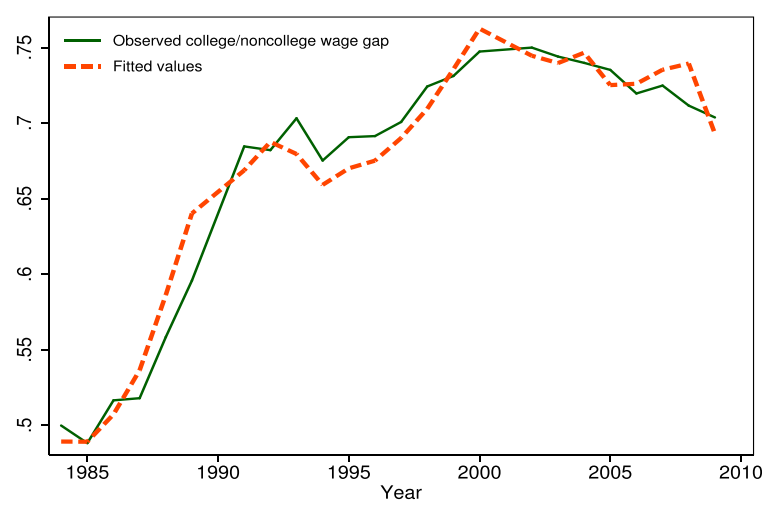

Figure 4 Prediction for the college/noncollege wage gap. The predicted wage gap is the fitted value from an OLS regression of the college/noncollege wage gap for the years 1984 to 2009 on a constant and the college/noncollege relative supply measure (Column (1) of Table 4). The college/noncollege log relative supply index is the logarithm of the ratio of college equivalent to noncollege equivalent labor supply in efficiency units in each year. 
The minimum wage is not relevant to explain the skill premium. High-skill workers earn wages high enough not to be affected by the minimum wage, and the ability of the minimum wage to raise wages above the first quartile is also limited (Centeno et al. 2011). On the other hand, changes in labor market conditions have a substantial effect on the wage gap. A 5 percentage point increase in the natural rate of unemployment, similar to the one observed from the late 90 s to 2009, can explain a reduction in the wage gap of around $20 \mathrm{log}$ points. The reduction in inequality associated with a deterioration in the economic fundamentals can be explained by the greater destruction of low-paid jobs in recessions. This composition effect shifts the mass of the wage distribution to the right, which explains average (macroeconomic) wage growth in recessions (Abraham and Haltiwanger 1995) and also the reduction in wage inequality. However, it raises issues of income inequality, which is likely to increase with unemployment.

Figure 5 presents the college relative supply and wage premium series between 1984 and 2009, deviated from a linear trend. This chart does an excellent job in describing how supply and demand forces shaped wage inequality in Portugal. In Figure 5, the wage gap and relative supply show, as expected, opposite movements. Whenever relative supply is below the trend, the wage gap is above its trend. For instance, the acceleration in relative supply of college graduates since the early 90 s is coupled with a reduction in the detrended wage differential.

\subsection{The cohort effects of relative supply change}

As shown in Table 2, the evolution of wage inequality differed significantly across and within age-skill groups. The increase in inequality was concentrated in older workers, especially among the more educated. We take a closer look at this pattern in Figure 6 by comparing the evolution of the college premium and college relative supply for workers in different experience cohorts. The college wage gap increased in a similar way for all groups until the first half of the 90s, but since the mid 90s the college premium has jumped almost $20 \log$ points for those with more than 20 years of experience and it fell by $14 \log$ points for young college graduates. If workers with the same education but different levels

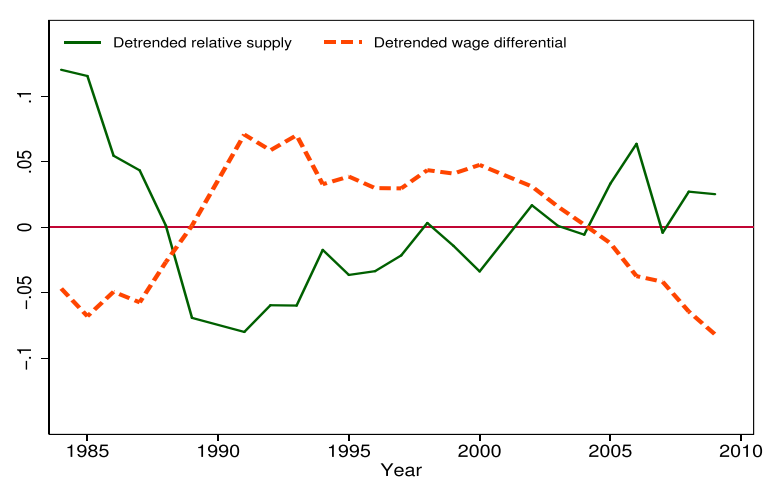

Figure 5 College/noncollege'relative supply and wage differential. The composition adjusted college wage premium is calculated using Quadros de Pessoal data, sorted into gender-education-potential experience groups. We have two gender, five education and four potential experience groups. Mean log wages for broader groups in each year represent weighted averages of the relevant cell means using a fixed set of weights equal to the mean share of total employment for each group over 1984-2009. The detrended supply and wage series are the residuals from separate OLS regressions of the relative supply and relative wage measures on a constant and a linear trend. 

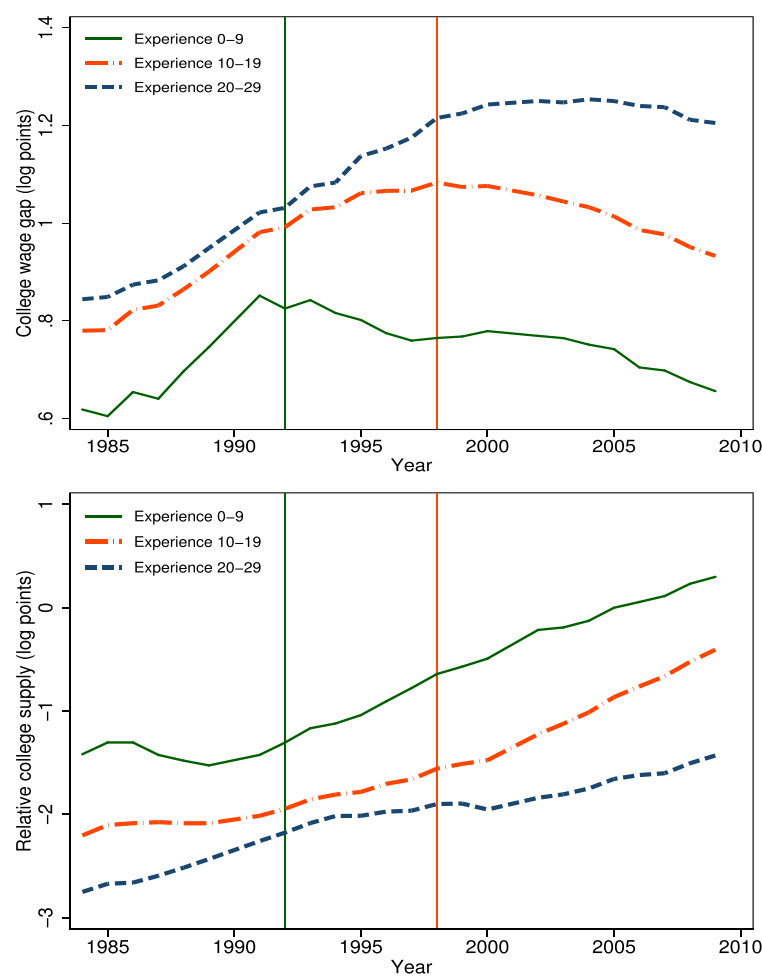

Figure 6 Upper panel: Composition-adjusted log relative college/noncollege wage gap by potential experience. Lower panel: Composition-adjusted log relative college/noncollege supply by potential experience. See notes to Figure 5 for the details on the construction of supply and wage measures. Vertical lines represent the changes in the trends of relative college supply for the experience group 0-9 (1992) and experience group 10-19 (1998).

of experience are imperfect substitutes in production, we may expect these developments to be related with differences in the relative skill supplies in each experience-group (Card and Lemieux 2001). Consistent with this view, Figure 6 also shows a more rapid increase in the supply of college graduates among the less experienced workers since 1995 (133 log points, compared to $60 \log$ points for the older group). The shifts in the relative supply of skills presented in Table 2 and Figure 6 show important differences among different age (and potential experience) cohorts.

The Card and Lemieux (2001) model relaxes the hypothesis that different experience groups with the same education are perfect substitutes in production. The production function assumes that aggregate output depends on two CES subaggregates of college and noncollege labor, in which the elasticity of substitution is a function of the partial elasticity of substitution between different experience groups with the same level of education $\left(\sigma_{E}\right)$. In the model, shifts in the experience-group-specific relative supply are expected to shift the experience profile of the college wage gap, with an effect that depends on the size of $\frac{1}{\sigma_{E}}$. The model estimated becomes:

$$
\ln \left(\frac{w_{c j t}}{w_{n j t}}\right)=\beta_{1}\left[\ln \left(\frac{N_{c j t}}{N_{n j t}}\right)-\ln \left(\frac{N_{c t}}{N_{n t}}\right)\right]+\beta_{2} \ln \left(\frac{N_{c t}}{N_{n t}}\right)+\beta_{3} X_{t}+\gamma_{j}+\epsilon_{j t},
$$

where $j$ indexes the experience groups, the $\gamma_{j}$ are the experience group fixed effects, and $X_{t}$ includes the same covariates as in Table 4. Under the assumptions of Card and Lemieux (2001), we can interpret $\frac{-1}{\beta_{2}}$ as an estimate of $\sigma$, and $\frac{-1}{\beta_{1}}$ as an estimate of $\sigma_{E}$. 
The results are presented in Table 5. The first two columns present pooled estimates for the four experience groups allowing for group specific intercepts. These estimates point to significant effects of both own-group and aggregate supplies on the college wage gap by experience group. The aggregate elasticity in column (1) is close to 2 , similar to the one obtained in Table 4. The implied partial elasticity of substitution between experience groups within the same education group is close to 3 . This is slightly smaller than the one reported in Autor et al. (2008) for the U.S. (3.6) and the estimates by Card and Lemieux (2001) for the U.S., U.K., and Canada. The Portuguese labor market shows a great deal of wage sensitivity to supply conditions similar to Anglo-Saxon labor markets.

The differences in own-group relative college supply growth can explain about half of the evolution of the college wage premium since 1984 and almost all the evolution since 1995. In the later period, the college wage premium decreased $14 \log$ points for the less experienced and increased $7 \log$ points for the group with 20-29 years of experience (see left panel of Figure 6). Over the same period, the difference in own-group relative supply between the two groups was $53 \log$ points (with a faster increase for the less experienced: see bottom panel of Figure 6). Thus, using the implied own-group inverse elasticity of column (1), we find that the quicker increase in college supply for the younger group explains $17 \log$ points of the difference in the wage gaps between the two experience groups. That is $82 \%$ of the $21 \log$ points difference in wage premium variations in the period.

These results point to the potential importance of different sensitivities of the wage gap to own-group and aggregate supplies across experience groups. This is reported in the remaining columns of Table 5 . The demand shifts are more important for prime-age individuals, those with between 10 and 29 years' experience. The wage-gap elasticity of own-group supply decreases with experience; it is higher for younger individuals (3.9 for

Table 5 Regression models for the college/noncollege log wage gap by experience group

\begin{tabular}{|c|c|c|c|c|c|c|c|c|c|c|}
\hline & \multicolumn{10}{|c|}{ Potential experience groups } \\
\hline & \multicolumn{2}{|c|}{ All groups } & \multicolumn{2}{|c|}{$0-9$ years } & \multicolumn{2}{|c|}{$10-19$ years } & \multicolumn{2}{|c|}{$20-29$ years } & \multicolumn{2}{|c|}{$30-39$ years } \\
\hline & (1) & (2) & (3) & (4) & (5) & (6) & (7) & (8) & (9) & (10) \\
\hline \multirow[t]{2}{*}{ Own minus aggregate supply } & -0.324 & -0.323 & -0.209 & -0.254 & -0.584 & -0.548 & 0.132 & 0.059 & 0.427 & 0.200 \\
\hline & 0.010 & 0.009 & 0.129 & 0.110 & 0.043 & 0.112 & 0.161 & 0.064 & 0.197 & 0.116 \\
\hline \multirow[t]{2}{*}{ Aggregate supply } & -0.578 & -0.400 & -0.614 & -0.435 & -0.459 & -0.464 & -0.242 & -0.106 & -0.163 & -0.034 \\
\hline & 0.105 & 0.107 & 0.187 & 0.176 & 0.064 & 0.068 & 0.308 & 0.125 & 0.085 & 0.054 \\
\hline \multirow[t]{2}{*}{ Log real minimum wage } & & -0.174 & & -0.188 & & -0.016 & & -0.141 & & -0.130 \\
\hline & & 0.314 & & 0.325 & & 0.189 & & 0.198 & & 0.160 \\
\hline \multirow[t]{2}{*}{ Natural unemployment rate } & & -0.036 & & -0.027 & & -0.004 & & -0.052 & & -0.027 \\
\hline & & 0.008 & & 0.008 & & 0.012 & & 0.005 & & 0.004 \\
\hline \multirow[t]{2}{*}{ Time } & 0.048 & 0.042 & 0.044 & 0.038 & 0.040 & 0.041 & 0.035 & 0.033 & 0.040 & 0.030 \\
\hline & 0.007 & 0.008 & 0.011 & 0.011 & 0.004 & 0.005 & 0.017 & 0.008 & 0.007 & 0.005 \\
\hline \multirow[t]{2}{*}{ Constant } & -0.734 & 0.543 & -0.782 & 0.544 & -0.325 & -0.267 & 0.194 & 1.291 & 0.630 & 1.451 \\
\hline & 0.284 & 1.107 & 0.585 & 1.109 & 0.168 & 0.665 & 0.847 & 0.731 & 0.260 & 0.562 \\
\hline No. of observations & 96 & 96 & 24 & 24 & 24 & 24 & 24 & 24 & 24 & 24 \\
\hline$R^{2}$ & 0.882 & 0.906 & 0.738 & 0.848 & 0.972 & 0.972 & 0.903 & 0.987 & 0.969 & 0.991 \\
\hline
\end{tabular}

Notes: Standard errors in italic. Each column presents an OLS regression of the fixed-weighted college wage premium on the indicated variables. The college/noncollege wage premium is calculated as the average for each potential experience group. The minimum wage is deflated by the consumer price index. Columns (1) and (2) also include dummy variables for the four potential experience groups used in the Table. The source for labor supply and wages is the Quadros de Pessoal, 1984-2009. 
those with less than 10 years of experience and 1.7 for those with experience between 10 and 19 years). On the other hand, the elasticity of aggregate supply increases with the experience level. The least sensitive are the youngest individuals; the elasticity is very low (less than 2) for the less experienced workers, and close to 3 for those with 10-19 years of experience. Interestingly, the wage gap of older workers is not sensitive to changes in supply (either own-group or aggregate), which can be interpreted as a shield effect generated by labor market experience and institutional arrangements. The natural unemployment rate has a significant negative impact on the college wage premium at the early stages of the workers' career. Prime-aged individuals (with 10-19 years of experience) are shielded from labor market conditions, but those with more than 20 years of experience have the largest sensitivity to fluctuations in the natural rate.

The shifts in cohort-specific supply of highly educated workers, matched with a steady increase in relative demand for skills, provide a good explanation for the observed changes in education-related wage gaps. The simple supply-demand framework used in this section can account for a great deal of the evolution of between-group inequality. The rise in the wage premium during the 80s and first half of the 90s and the slowdown observed thereafter are associated with the differential rise in relative supply by experience groups.

\subsection{The role of the minimum wage}

Changes in lower-tail inequality were more contained over the entire period. One possible candidate to explain the modest changes observed is the minimum wage. The debate for the U.S. is alive, and the evidence is mixed (Autor et al. 2008; Lemieux 2006). We follow this line of research and try to evaluate the role of the minimum wage in explaining wage inequality in Portugal.

The minimum wage is usually considered an important feature of the wage-setting institutions in the Portuguese economy (Cardoso 1998). However, the impact of the minimum wage on wage inequality in Portugal remains an open issue. It directly affects a sizeable portion of salaried workers (from $3 \%$ in 1984 to $14 \%$ in 2009, Table 1), but its impact is not fully described by the simple share of workers who earn the minimum wage (Centeno et al. 2011).

The minimum wage ought to affect primarily inequality in the lower-tail of the wage distribution, particularly among female workers, who have a higher incidence of minimum wage jobs. To test this hypothesis for both genders separately, we repeat the Katz and Murphy methodology for the lower-tail wage gap (50/10 ratio) and for the upper-tail wage gap (90/50 ratio). The results, displayed in Table 6, show a negative and significant impact of the minimum wage. A log-point rise in the minimum wage is associated with a 0.3 log-point compression in lower-tail inequality for males and a 0.5 log-point reduction for females. As expected, the coefficient is non-significant for both genders in the 90/50 wage-gap regressions. In the upper-tail, the elasticity of substitution is smaller for females. A possible explanation for this rests on the higher rates of female graduation and the increase in their participation rate, which has resulted in cohorts less substitutable due to differences in productive characteristics such as education and experience.

\subsection{Polarization}

The evolution of wage inequality in Portugal shows a big increase in upper- and lowertail inequalities until the mid 90s. However, afterwards the wage distribution polarizes, 
Table 6 Regression models for the $90 / 50$ ad $50 / 10$ wage ratios

\begin{tabular}{|c|c|c|c|c|}
\hline & \multicolumn{2}{|c|}{ Male } & \multicolumn{2}{|c|}{ Female } \\
\hline & $90 / 50$ & $50 / 10$ & $90 / 50$ & $50 / 10$ \\
\hline \multirow[t]{2}{*}{ College/Noncollege relative supply } & -0.065 & -0.185 & -0.267 & 0.006 \\
\hline & 0.037 & 0.048 & 0.072 & 0.033 \\
\hline \multirow[t]{2}{*}{ Log real minimum wage } & -0.030 & -0.265 & -0.331 & -0.457 \\
\hline & 0.110 & 0.141 & 0.210 & 0.098 \\
\hline \multirow[t]{2}{*}{ Natural unemployment rate } & -0.011 & -0.016 & -0.010 & -0.008 \\
\hline & 0.003 & 0.004 & 0.005 & 0.003 \\
\hline \multirow[t]{2}{*}{ Time } & 0.020 & 0.018 & 0.035 & 0.007 \\
\hline & 0.003 & 0.003 & 0.005 & 0.002 \\
\hline \multirow[t]{2}{*}{ Constant } & 0.528 & 0.901 & 1.085 & 1.924 \\
\hline & 0.387 & 0.499 & 0.743 & 0.346 \\
\hline No. of observations & 24 & 24 & 24 & 24 \\
\hline$R^{2}$ & 0.992 & 0.828 & 0.969 & 0.934 \\
\hline
\end{tabular}

Notes: See notes of Table 4. Standard errors in italic.

with a continuous increase in the upper half and a reduction in the lower half of the distribution. This polarization is observed in overall inequality, residual inequality and in educational wage gaps, a result also obtained for a large number of countries in Goos et al. (2009).

What can account for this differentiated evolution at both ends of the wage distribution in the two periods? The short answer to this question has two parts. The Portuguese economy went from a skill-biased technological trend in the 80s and 90s, matched with a lack of skill supply, to a polarization of labor demand, matched with an increase in college graduates.

We follow Goos and Manning (2007) and look for shifts in the employment structure consistent with the "polarization of work", where the increased demand for skills of higher-educated workers is matched with a reduced demand for intermediate-skill workers, while the demand in occupations with low levels of education remained stable.

These shifts in the demand for skills can be the result of multiple developments. Goos et al. (2009) identify three possible origins for this polarization of work: (i) the "routinization" hypothesis of Levy et al. (2003); (ii) the effects of globalization that characterize the process of an international division of labor, in which global outsourcing plays a relevant role; and (iii) a link between employment demand and inequality, as more unequal societies create a demand for low-skill services (Manning 2004).

The Portuguese economy was particularly sensitive (and exposed) to some of these processes. It faced rapid integration into the European economy after joining the European Community in 1986, a much richer economic area, which implied a substantial increase of its degree of openness to technological shocks. In the more recent period, demand has increased for low-skill services, mostly related to retail, tourism and real estate (together with a mild boom in construction). In Portugal, both demand and supply have evolved 
in the same direction since 1995, while in other developed economies there has been a reduction in the pace of skill growth in the more recent period.

The polarization of work is a demand-side phenomenon characterized by rising relative demand for high- and low-skill occupations. Its implications are testable: equilibrium wages and quantities should both increase, resulting in a positive covariation. We apply a methodology similar to the one in Goos and Manning (2007) to our data, using the educational level to proxy for the occupational skill level.

Figure 7 presents the change in the shares in total employment from 1984 to 1994 and from 1996 to 2009 by occupation skill percentile, using the education level as proxy for the skill intensity. ${ }^{2}$ This exercise uses 996 occupations for the first period and 348 for the subsequent period, which correspond to the 4-digit occupations in the National Classification of Occupations. There are strikingly different patterns in the recomposition of employment between periods. In the first period, there was a significant reduction in the share of employment in occupations with lower skills and an increase in occupations with higher skills. In sharp contrast, in the post-1995 period, employment growth seems to have polarized. There is a sizeable increase in the share of employment for occupations with higher skills, a reduction in intermediate-skill jobs and also an increase in the share of low-skill jobs.

In the polarization period, the professions with intermediate skills (average schooling between 8 and 10 years) that decreased the most include, for instance, "Sales personnel", "Electro-mechanical workers", "Clerical workers", and "Non-qualified workers in manufacturing". In the same period, the professions that increased the most include both low- and high-qualified workers, for instance, "Cooks", "Truck drivers", and "Janitors" (with average schooling of 5 years) and "Nurses", "Engineers", "Information and technology analysts" (with average schooling of 14 or more years). This shows that the Portuguese economy is integrated in the world economy and faced the three main origins of polarization identified above. Declining demand for routine occupations, e.g. clerical jobs, and increasing demand for jobs characterized by abstract reasoning and manual tasks, e.g. IT and cooks. This result is in line with Fonseca et al. (2013).

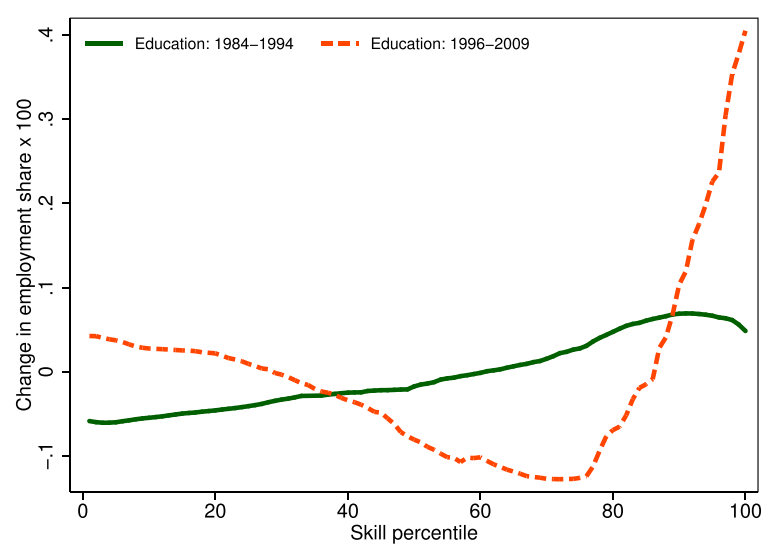

Figure 7 Change in occupation employment share by occupational skill percentile. The figure plots log changes in employment shares by 1984 and 1996 occupational skill percentile rank using a locally weighted smoothing regression (with bandwidth 0.8 ). We measure the occupational skill by the employment-weighted percentile rank of the occupation's mean years of education. 
This trend in employment growth was matched by similar changes in the wage distribution, as shown in Figure 8. The real wage evolved monotonically with skills during the first period, with negative real wage growth up to the 40th percentile of the wage distribution and positive gains thereafter, particularly above the 3rd quartile. In the post-1995 period, wage growth follows a U-shaped pattern, with the lowest gains observed between the 30th and 60th wage percentiles. This means that labor market prices and quantities covary positively in each of these two periods - a demand dominated evolution.

This positive covariation can be assessed in a more formal way by regressing the $(\log )$ employment share estimated in Figure 7 on the changes in log wages by the wage percentile of Figure 8. We estimate a regression separately for each period using data from the 4th to the 97th percentiles of the wage and skill distributions. We obtain a coefficient of 0.391 ( $t$-ratio of 27.54) for the 1984-1995 period and 1.471 (t-ratio of 7.97) for the 1995-2009 period. The monotone increase in wage inequality in the 80s and 90s and the "polarized" growth of wage inequality in the more recent period are paralleled by conformable changes in employment by skill.

\section{Conclusion}

Supply and demand market forces resulted in an increase in wage inequality, in particular at the top of the wage distribution. The upper-tail inequality increase was bigger before the mid-90s than afterwards. We interpret this slowdown not as a reduction in demand pressure, but as the result of an extraordinary increase in the supply of skills. Two results are particularly important for this conclusion to be drawn. First, in the post-1995 period, we observe a polarization of work - a demand phenomenon, characterized by relative employment and wage gains for low- and high-skill workers. Second, more skilled and younger cohorts experience a reduction in the college wage gap, a consequence of the increase in the supply of skills concentrated in this younger group.

Lower-tail inequality increased in the pre-1995 period (especially in the 1987-1995 period) and declined (or at best remained stable) subsequently. The behavior of lowertail wage changes is mainly explained by negative demand shocks during the first period and by the polarization of work and the minimum wage more recently, which benefited low-wage jobs (against intermediate-skill jobs) and helped in reducing inequality.

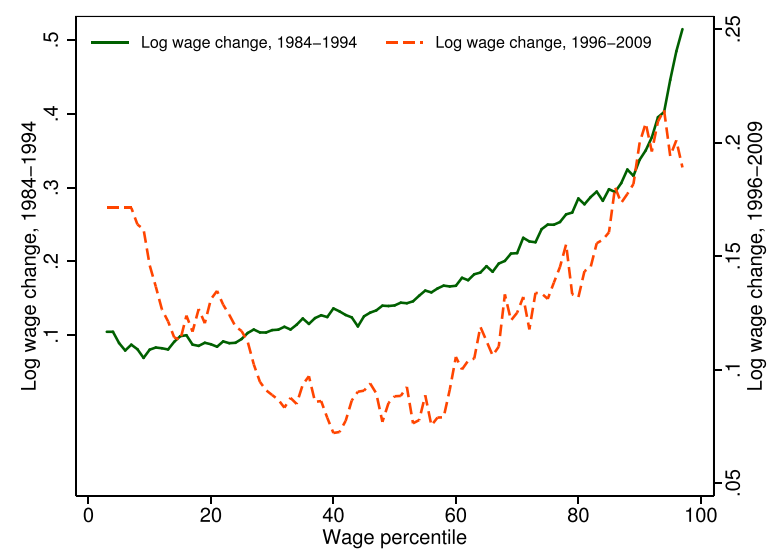

Figure 8 Change in real wages, by wage percentile. See notes to Figure 1. 
We see these results as evidence that market forces play a key role in understanding the changes in the wage distribution in Portugal. This is in accordance with the available evidence for other countries, such as Germany, the U.K., and the U.S. The role of the institutional setting to contain inequality developments is of major relevance to the debate in European countries that share a similar regulatory environment. We show that the minimum wage can contain lower-tail inequality - though, we ignore the impact on employment - and that increasing educational achievement is the main supply factor to curb wage inequality.

\section{Endnotes}

${ }^{1}$ We also excluded the first two years of the data, 1982 and 1983, due to potential under-reporting of firms and the quality of some variables.

${ }^{2}$ In 1995, the occupational codes changed, and the mapping of pre- and post-1995 classifications is not perfect. For this reason, we use them separately and exclude 1995 due to transition problems evident in the occupational coding.

\section{Appendix}

\section{Sample selection}

The selection criteria applied to our samples consisted in keeping all wage spells corresponding to full-time workers earning at least the minimum wage. These restrictions were imposed to make our results more comparable with those reported in key papers in the field, such as Autor et al. (2006).

\section{Education and age}

The education variable distinguishes five groups. This number of categories aimed at capturing the changes in mandatory schooling that were faced by workers in our sample. The five categories are: less than 4 years of schooling, between 4 and 6 years of schooling, 7 to 9 years of schooling, 10 to 12 years of schooling, and a college degree. Whenever necessary these categories are aggregated in broader groups.

The age variable considers eight age groups: less than 25 years old; 25-29; 30-34; 35-39; 40-44; 45-49; 50-54; and more than 54 years old.

\section{Relative supply measures}

We calculate the quantities supplied of college and noncollege graduates using the QP samples. We construct a labor quantity sample measured in efficiency units for all workers with 0 to 39 years of potential experience. These workers are split into 400 gender $\times$ education $\times$ potential experience cells. Experience groups are single-year categories of 0 to 39 years; education groups are the same as above. The quantity data are merged with price data containing mean real wage by year, gender, potential experience, and education. To compute the efficiency units, we use mean real wage by year, gender, education, and age.

\section{Education wage differentials}

The data are sorted into gender-education-potential experience groups based on a breakdown of the data into two gender, five education, and four potential experience categories $(0-9,10-19,20-29$, and 30 or more years). Log monthly base wages of full-time workers are regressed in each year separately by gender on the dummy variables for four education 
categories, a quartic in experience and interactions of the experience quartic with the education dummies. The composition adjusted mean log wage for each of the forty groups in a given year is the predicted average log wage from these regressions for each relevant experience group. Mean log wages for broader groups in each year represent weighted averages of the relevant cell means, using a fixed set of weights, equal to the mean share of total employment by each group over 1984 through 2009 .

\section{Computing counterfactuals}

The observed wage density at time $t, f(w \mid t)$, can be decomposed into the product of the density of observable wages conditional on observable attributes $x$ at time $t, g(w \mid x, T=t)$, and the density of the same attributes, $h(x \mid T=t)$. Formally,

$$
f(w \mid T=t)=\int g(w \mid x, T=t) h(x \mid T=t) d x
$$

and similarly for time $T=t^{\prime}$.

In order to compute the counterfactual wage distribution in year $t$ that would have prevailed if the workforce attributes were the same as in year $t^{\prime}$, one needs to re-weight the "price" function, $g(w \mid x, T=t)$, by the ratio of the "composition" functions, $\frac{h\left(x \mid T=t^{\prime}\right)}{h(x \mid T=t)}$. As shown by DiNardo et al. (1996), this ratio can be easily calculated by noting that $\frac{h\left(x \mid T=t^{\prime}\right)}{h(x \mid T=t)}=\frac{\operatorname{Pr}\left(T=t^{\prime} \mid x\right)}{\operatorname{Pr}(T=t \mid x)} \times \frac{\left(1-\operatorname{Pr}\left(T=t^{\prime}\right)\right)}{\operatorname{Pr}\left(T=t^{\prime}\right)}$. Notice that the reweighting function can be computed by using a dichotomous variable model - logit or probit - in the pooled data for years $t$ and $t^{\prime}$. In our case, the set of conditioning variables includes dummy variables for five levels of schooling and eight age groups, and all possible interaction terms between education and age dummies.

The same principle can be applied to decompose residual inequality; the price function $g(w \mid x, T=t)$ is replaced with the residual price function $g(\epsilon \mid x, T=t)$. The residuals, $\epsilon$, are obtained from a regression of log wages on the same set of attributes listed above.

\section{The Katz and Murphy framework}

In Katz and Murphy (1992) aggregate production depends only on the quantities of skilled and unskilled workers. We take as skilled workers those with a college degree, and unskilled workers are those without a college degree. The CES function stipulates an aggregate elasticity of substitution between the two types of labor. Aggregate output can be written as:

$$
Q_{t}=\left[\alpha_{t}\left(a_{t} N_{c t}\right)^{\rho}+\left(1-\alpha_{t}\right)\left(b_{t} N_{n t}\right)^{\rho}\right]^{\frac{1}{\rho}},
$$

where $N_{c t}$ and $N_{n t}$ are the quantities employed of college and noncollege equivalents, $a_{t}$ and $b_{t}$ are the college and noncollege labor augmenting technological change, $\alpha_{t}$ is a technology parameter, and $\rho$ is the production parameter. Skill-biased technological changes imply an increase in $\frac{a_{t}}{b_{t}}$ or $\alpha_{t}$. The aggregate elasticity of substitution can be computed as $\frac{\sigma=1}{(1-\rho)}$.

Under the assumption that college and noncollege equivalents are paid their marginal productivity, we can use the expression for aggregate output to solve for the college wage differentials:

$$
\ln \left(\frac{w_{c t}}{w_{n t}}\right)=\left(\frac{1}{\sigma}\right)\left[D_{t}-\ln \left(\frac{N_{c t}}{N_{n t}}\right)\right]
$$


where $D_{t}$ indexes relative demand shifts favoring college graduates. The greater $\sigma$ is, the smaller the impact of shifts in relative supplies on relative wages, and the greater must be the fluctuations in demand shifts to explain the time series variation of relative wages for given time series variation of relative quantities.

\section{Competing interests}

The IZA Journal of European Labor Studies is committed to the IZA Guiding Principles of Research Integrity. The authors declare that they have observed these principles.

\section{Acknowledgments}

We acknowledge the financial support provided by FCT's grant PTDC/EGE-ECO/112177/2009. We thank José Ferreira Machado and Ana Rute Cardoso for helpful discussions. We are grateful to Lucena Vieira for the outstanding data handling of the Quadros de Pessoal dataset. Opinions expressed herein do not necessarily reflect the views of the Banco de Portugal. Any errors are of our responsibility.

Responsible editor: Sara de la Rica

Received: 17 March 2014 Accepted: 28 August 2014

Published: 12 Dec 2014

\section{References}

Abraham KG, Haltiwanger JC (1995) Real wages and the business cycle. J Econ Lit 33(3):1215-1264

Autor DH, Levy F, Murnane RJ (2003) The skill content of recent technological change: An empirical exploration. The Q J Econ 118(4):1279-1333

Autor DH, Donohue III JJ, Schwab SJ (2006) The cost of wrongful-discharge laws. Rev Econ Stat 88:211-231

Autor DH, Katz LF, Kearney MS (2008) Trends in U.S. wage inequality: Revising the revisionists. Rev Econ Stat 90(2):300-323

Card D, Lemieux T (2001) Can falling supply explain the rising return to college for younger men? A cohort-based analysis. Q J Econ 116(2):705-746

Cardoso AR (1998) Earnings inequality in Portugal: High and rising? Rev Income Wealth 44(3):325-343

Cardoso, A R (2004) Jobs for young university graduates: is it worth having a degree? Institute for the Study of Labor (IZA). Discussion paper series 1311

Centeno M, Maria J, Novo A (2009) Unemployment: A supply, demand, and institutions approach. In: N Alves AL, Centeno M (eds). The Portuguese Economy in the Context of Economic, Financial and Monetary Integration. Banco de Portugal, Lisbon. pp 215-258

Centeno M, Duarte C, Novo A (2011) The impact of the minimum wage on low-wage earners, Vol. 10. Economic Bulletin, Banco de Portugal

DiNardo J, Fortin NM, Lemieux T (1996) Labor market institutions and the distribution of wages, 1973-1992: A semiparametric approach. Econometrica: J Econometric Soc 64:1001-1044

Dustmann C, Ludsteck J, Schönberg U (2009) Revisiting the German wage structure. Q J Econ 124(2):843-881

Fonseca T, Lima F, Pereira S (2013) Technological change, routinization and job polarization: Evidence from a middle-income country. mimeo, 3rd Linked employer-employee data (LEED) Workshop

Goldin CD, Katz LF (2008) The race between education and technology. Belknap Press, Cambridge, MA.

Goos M, Manning A (2007) Lousy and lovely jobs: The rising polarization of work in Britain. Rev Econ Stat 89(1):118-133

Goos M, Manning A, Salomons A (2009) Job polarization in Europe. Am Econ Rev 99(2):58-63

Katz LF, Murphy KM (1992) Changes in relative wages, 1963-1987: Supply and demand factors. The Q J Econ 107(1):35-78

Lemieux T (2006) Increasing residual wage inequality: Composition effects, noisy data, or rising demand for skill? Am Econ Rev 96(3):461-498

Machado JAF, Mata J (2005) Counterfactual decomposition of changes in wage distributions using quantile regression. J Appl Econometrics 20(4):445-465

Machado, J A F, Mata J (2001) Earning functions in Portugal 1982-1994: Evidence from quantile regressions. Empir Econ 26(1):115-134

Manning A (2004) We can work it out: The impact of technological change on the demand for low-skill workers. Scott J Pol Econ 51(5):581-608

Martins PS, Pereira PT (2004) Does education reduce wage inequality? Quantile regression evidence from 16 countries. Labour Econ 11(3):355-371

OECD (2011) Divided We Stand. OECD, Paris

10.1186/2193-9012-3-23

Cite this article as: Centeno and Novo: When supply meets demand: wage inequality in Portugal. IZA Journal of European Labor Studies 2014, 3:23 